\title{
KERANGKA PENGENDALIAN INTERN MODEL COMITEE ON SPONSORING ORGANIZATION (COSO): IMPLEMENTASI DALAM PENYALURAN PEMBIAYAAN PADA KOPERASI SYARIAH BAITUL MUTTAQIN KOTA BANDUNG
}

\section{FRAMEWORK FOR INTERNET COMITEE ON SPONSORING ORGANIZATION (COSO) CONTROL MODEL: IMPLEMENTATION IN FINANCING DISTRIBUTION IN THE SYARIAH BAITUL MUTTAQIN COOPERATION IN BANDUNG CITY}

\author{
Abin Suarsa ${ }^{1}$, Mujiman ${ }^{2}$ \\ Sekolah Tinggi Ilmu Ekonomi Muhammdiyah Bandung \\ abinsuarsa@stiemb.ac.id ${ }^{1}$
}

\begin{abstract}
Abstrak
Perkembangan ekonomi yang mengalami tren penurunan berdampak pada pelaku bisnis yang mengakibatkan berkurangnya daya beli serta berimbas pada koperasi. Banyak anggota koperasi yang tidak mampu membayar kewajibannya sehingga terjadi pembiayaan bermasalah. Pengendalian diperlukan untuk meminimalkan pembiyaan bermasalah. Tujuan penelitian ini untuk mengetahui bagaimana Kerangka Pengendalian Comitee On Sponsoring Organization (COSO) dalam mengendalikan prosedur pemberian pembiyaan implementasi penerapan pada Koperasi Syariah Baitul Muttaqin Bandung sehingga akan meningkatkan kualitas pembiayaan. Penelitian ini merupakan penelitian kualitatif dengan menggunakan tiga metode pengumpulan data yaitu: partisipasi, observasi dan wawancara. Pengolahan data mengacu pada studi pustaka yang kemudian dianalisis dengan menggunakan analisis deskriptif dan menganalisis keseuaian antara kriteria dan praktik implementasi sistem pengendalian internal dengan menggunakan triangulasi.

Hasil penelitian ini menunjukkan bahwa pengendalian internal Koperasi Syariahh Baitul Muttaqin sudah menerapkan kerangka pengendalian Comittee On Spronsoring Organization walaupun masih ada kekurangan. Efektifitas penerapan ini dapat dibuktikan dengan tingkat resiko pembiayaan bermasalah yang rendah, yakni dibawah $5 \%$.
\end{abstract}

Kata Kunci: pengendalian internal, comittee on spronsoring organization, pembiyaan koperasi

\begin{abstract}
Declining trends Economic developments have an impact on businesses that result in reduced purchasing power and impact on cooperatives. Many members of cooperatives are unable to pay their obligations resulting in non-performing loans. Control is needed to minimize problem loans. The purpose of this research is to know how COSO Control Framework in controlling lending implementation procedure on Sharia Baitul Muttaqin Cooperative so that will improve credit quality. This research is a qualitative research using three methods of data collection are: participation, observation and interview. Data processing refers to literature study which is then analyzed by using descriptive analysis and analyze the harness between criteria and practice implementation of internal control system using triangulation.

The results of this study indicate that the internal control of the Syariahh Baitul Muttaqin Cooperative has implemented the Committee on Sponsorship Organization control framework even though there are still shortcomings. The effectiveness of this implementation can be proven by the low level of risk financing problems, which is below $5 \%$.
\end{abstract}

Keywords: internal control, committee on sponsoring organization, cooperative financing

\section{PENDAHULUAN}

Dalam hubungan antara manusia sebagai makhluk sosial, manusia akan hidup bersama dan saling membutuhkan satu sama lainnya. Kebersamaan dan saling membutuhkan satu sama lain menimbulkan aktifitas gotong royong. Koperasi merupakan perwujudan dari sifat kerja sama yang 
telah mengakar pada masyarakat Indonesia. Koperasi merupakan lembaga ekonomi strategis yang mampu menjadi penarik dan pendorong seluruh kegiatan ekonomi. Melalui koperasi, masyarakat secara kolekf dan nyata dapat menciptakan dan memperoleh nilai tambah, keuntungan dan kesempatan usaha yang lebih besar (Sastrawidjaja, 2015)

Dalam implementasinya, koperasi syariah memiliki peran untuk mengumpulkan dan menyalurkan dana kepada anggota koperasi sebagi modal pada sektor usaha mikro, kecil dan menengah (UMKM). Koperasi syariah mampu memberikan layanan pembiayaan dengan sistem bagi hasil dengan proses yang tidak rumit.

Dalam praktik penyaluran pembiayaan, ada unsur risiko dan ketidakpastian. Untuk meminimalkan risiko dan ketidakpastian diperlukan pengendalian. Untuk mencapai tujuan pengendalian tersebut, sumber daya manusia merupakan faktor penting, karena keterbatasan sumber daya manusia mengakibatkan gangguan pada operasional organisasi (Purworini, 2014). Karyawan atau pengurus yang berkualitas dan terdidik merupakan persyaratan yang diperlukan untuk mengembangkan sistem pengendalian intern, yang merupakan prasyarat penting untuk proses audit secara keseluruhan dalam suatu organisasi (Ekaulandari, Ni Wayan Vani; Dwirandra, 2013). Sumber daya manusia memadai merupakan sebuah kendala, karena sumber daya yang memadai akan menambah biaya gaji yang harus dikeluarkan bagi Usaha Menengah, Kecil dan Mikro (UMKM), sehingga sering terjadi adanya karyawan yang memiliki tugas ganda (Nilawati, 2016). Risiko dan ketidakpastian yang sering terjadi dalam penyaluran dana kepada nasabah yaitu adanya pembiyaan bermasalah.

Sebagai contoh, fenomena kredit bermasalah pada Koperasi Simpan Pinjam Pandawa Mandiri mencapai Rp 3 Triliun. Pemberian kredit kepada para pedagang usaha kecil menengah (UKM) di pasar-pasar se-Jabodetabek ${ }^{1}$ yang termasuk anggota dan non anggota koperasi. Karena kredit macet dari para pedagang tersebut, koperasi ini tidak mampu mengembalikan modal para investor, sebagaimana yang diberitakan dalam media nasional, yakni majalah kontan. (2017)

Fenomena yang lain tentang kredit macet menimpa Koperasi Cipaganti pada tahun 2014. Koperasi tersebut mulai membuka kerja sama dengan nasabah pada 2008 dengan mendasarkan regulasi Peraturan Pemerintah Nomor 33 tahun 1998. Dalam peraturan tersebut koperasi diperbolehkan memperlibatkan pihak ketiga sebagai penanam modal. Dengan adanya kerja sama mitra koperasi itu, koperasi diwajibkan untuk membuat dan memberikan laporan tahunan mengenai transparansi penyertaan modal pihak ketiga. Namun, dari hasil penelusuran Dinas Koperasi, hanya sekali saja Koperasi Cipaganti menyampaikan laporannya, yaitu pada tahun 2012. Total dana yang terhimpun dari 8.700 mitra koperasi sebesar Rp 3,2 Triliun. Imbal hasil investasi yang dijanjikan koperasi kepada mitra sebesar 1,6 \% - 1,95 \% perbulan dan macet sejak Maret 2014 (https://bisnis.tempo.co).

Penelitian-penelitian sebelumnya menunjukan bahwa pembiyaan macet terutama disebabkan oleh lemahnya sistem pengendalian intern. Lemahnya pengendalian atas kepatuhan pemisahan fungsi akuntansi dengan fungsi keuangan seperti yang terjadi pada Koperasi Bank Perkreditan Rakyat Ngadirejo Pacitan menyebabkan terjadinya kredit bermasalah (Nikmatuniayah, 2014). Kurangnya pengendalian atas penilaian lama usaha calon nasabah menjadi penyebab macetnya pembiayaan di koperasi Mitra Usaha Jepara (H. Ismanto \& Diman, 2014). Penyebab kredit macet pada KPN Satya Bakti yaitu dari faktor internal dimana lemahnya aturan dalam prosedur pemberian kredit dilihat dari tahap penilaian, hanya dilakukan dengan pengamatan langsung, tanpa ada standar tertulis dan faktor eksternal dimana pinjaman tidak hanya dilakukan di KPN Satya Bakti saja tapi dikoperasi lainnya, sehingga terjadi tunggakan pembayaran (Kusuma, Ustriyana, \& SDJ, 2016). Adanya kesengajaan atau wanprestasi dari debitur untuk tidak membayar juga merupakan salah satu kredit bermasalah seperti yang terjadi pada Koperasi Serba Usaha Putra Dalem (Puspitaningrat \& Dharmakusuma, 2018). Kurangnya pengawasan berkelanjkutan atas munculnya kebankrutan, menurunya kemampuan membayar kredit, dan masalah keluarga menjadi faktor penyebab kredit macet pada Koperasi Swastiastu Singaraja (Utami, Zukhri, \& Cipta, 2014).

${ }^{1}$ Jabodetabek merupakan singkatan yang merujuk pada suatu lingkup wilayah meliputi: Jakarta, Bogor, Depok, Tangerang, dan Bekasi. 
Begitu juga pembiyaan bermasalah pada Bank Muamalat, yang disebabkan oleh penurunan omset dari nasabah dan sulitnya proses musyawarah dengan nasabah dalam penyelesainnya (Amalia, Thaif, Nasution, \& Sunarmi, 2013).

Penelitian dilaksanakan pada Koperasi Syariah Baitul Muttaqin dengan melihat bahwa ada hal menarik dari hasil wawancaya pendahuluan, bahwa walaupun dengan sumber daya manusia yang belum memadai, namun mampu menekan pembiayaan bermasalah. Maka sangat menarik untuk diteliti lebih dalam praktek-praktek syariah yang memungkinkan kinerja pembiayaan semakin baik. Karena koperasi tersebut menggunakan transaksi syariah yang miliputi prinsip tauhid, prinsip keadilan, prinsip maslahat, prinsip ta'awun, dan prinsip keseimbangan (Mursal, 2015).

Hasil penelitian ini diharapkan dapat memberikan kontribusi secara keilmuan tentang praktek pengendalian intern dalam ranah bisnis dengan ukuran bisnis yang kecil yang bisa melengkapi teori akuntansi terutama yang berhubungan dengan sistem akuntansi dan sistem pengendalian internal yang sudah ada. Kontribusi bagi pelaku bisnis pada Usaha Mikro Kecil dan Menengah bisa dijadikan rujukan sehingga mampu menekan pembiayaan bermasalah dan akan meningkatkan kinerja perusahaan.

Tujuan penelitian ini untuk mengetahui bagaimana Kerangka Pengendalian Comitee On Sponsoring Organization (COSO) dalam mengendalikan prosedur pemberian pembiyaan implementasi penerapan pada Koperasi Syariah Baitul Muttaqin Bandung sehingga akan meningkatkan kualitas pembiayaan.

Yang membedakan penelitian ini dengan penelitian sebelumnya terletak pada fokus keberhasilan koperasi syariah menekan tingkat kegagalan pembiayaan dan dikaitkan dengan sebuah model kerangaka pengendalian Comitee On Sponsoring Organization (COSO). Sementara penelitian lain memperlihatkan faktor-faktor yang menyebabkan kegagalan dalam penyaluran pembiayaan.

\section{TINJAUAN LITERATUR DAN FOKUS STUDI}

\section{Kerangka Pengendalian COSO}

Mengacu kepada konsep Internal Control System (ICS) yang dibuat oleh Committee on Sponsoring Organisation (COSO), yang kemudian diadopsi menjadi the Statement of Auditing Standard Number 55, mendefinisikan

“internal control as a process, affected by an entity's board of directors, managements, and other personnel, designed to provide reasonable assurance regarding the achievement of the objectives" (Messier, 2000).

Tujuan tersebut dikelompokkan menjadi tiga kategori yaitu:

1. reliability of financial reporting; Manajemen memikul baik tanggung jawab hukum maupun tanggungjawab profesional untuk memastikan bahwa informasi telah disajikan secara wajar sesuai dengan persyaratan pelaporan kerangka kerja akunansi seperti prinsip-prinsip yang berlaku umum.

2. compliance with applicable laws and regulations; semua organisasi publik, non publik, dan nirlama diwajibkan mentaati berbagai hukum dan peraturan.

3. effectiveness and efficiency of operations; Pengendalian dalam perusahaan akan mendorong pemakaian sumber daya secara efisien dan efektif, untuk mengoptimalkan sasaran-sasaran perusahaan (Guy, Alderman, \& Winters, 1999).

Sehubungan dengan komponen yang terdapat dalam International Control System (ICS), berikut lima komponen ICS berdasarkan klasifikasi yang dinyatakan dalam COSO (Guy et al., 1999). Kelima kriteria tersebut meliputi:

1. control environment;

2. risk assessment;

3. control activities;

4. information and communication; and

5. monitoring. 


\section{Control environment}

Terdiri atas tindakan, kebijakan, dan prosedur yang mencerminkan sikap manajemen puncak, para direktur, dan pemilik entitas secara keseluruhan mengenai pengendalian internal serta arti pentingnya bagi entitas itu.

\section{Risk assessment}

Tindakan manajemen untuk mengidentifikasi dan menganalisis risiko-risiko yang relevan dengan penyusunan laporan keuangan. Penilaian risiko diatur dalam ISA 315 yang meliputi: 1) risiko bisnis yang relevan dengan tujuan pelaporan keuangan; 2) estimasi berapa signifikannya risiko; 3) besarnya potensi terjadinya resiko; dan 4) tindakan untuk menangani risiko (Tuanakota,2013) dalam (Suryanto, Indriyani, \& Sofyani, 2017).

\section{Control activity}

Kebijakan dan prosedur yang membantu memastikan bahwa tindakan yang diperlukan telah diambil untuk menangani risiko guna mencapai tujuan entitas.

\section{Information and communication}

Untuk memahami perancangan sistem informasi, auditor menetukan (1) kelas transaksi utama entitas, (2) bagaimana transaksi dimulai, (3) catatan apa saja yang ada serta sifatnya, (4) bagaimana sistem itu menangkap peristiwa lain yang penting bagi laporan keuangan, (5) sifat serta rincian proses pelaporan keuangan.

\section{Monitoring}

Berhubungan dengan penilaian mutu pengendalian internal secara berkelanjutan atau periodik oleh manajemen untuk menentukan bahwa pengendalian itu telah beroperasi seperti yang diharapkan dan telah dimodifikasi sesuai dengan perubahan kondisi. Konsep pengendalian COSO dapat dilihat dalam gambar dibawah ini:

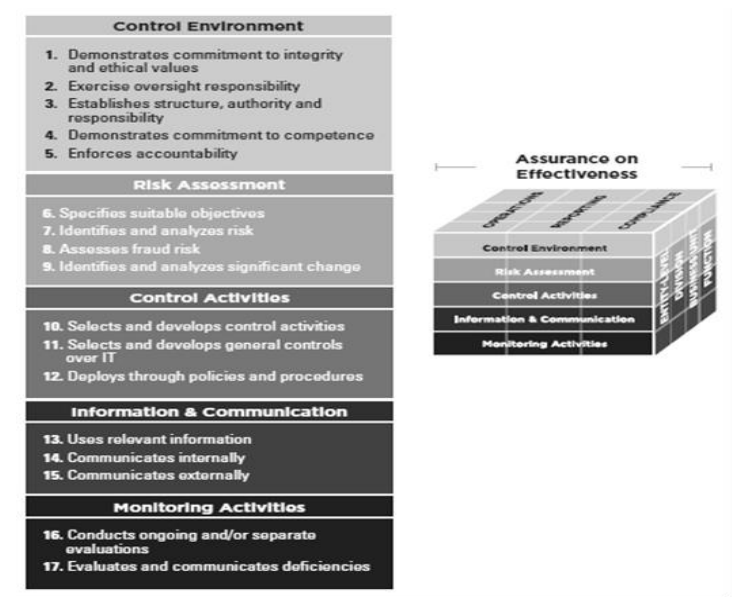

Gambar 1. Konsep Pengendalian COSO

Sumber: (Anderson \& Eubanks, 2015)

\section{Koperasi}

Menurut Undang-undang Perkoperasian Republik Indonesia Nomer 17 tahun 2012, yang dimaksud koperasi adalah badan hukum yang didirikan oleh orang perseorangan atau badan hukum koperasi, dengan pemisahan kekayaan para anggotanya sebagai modal untuk menjalankan usaha, yang memenuhi aspirasi dan kebutuhan bersama dibidang ekonomi, social dan budaya sesuai dengan nilai dan prinsip koperasi, yaitu :

a) Keanggotaan koperasi bersifat sukarela dan terbuka

b) Pengawasan oleh anggota diselenggarkan secara demokratis, 
c) Anggota berpartisipasi aktif dalam kegiatan ekonomi koperasi

d) Koperasi merupakan badan usaha swadaya yang otonom dan independen

e) Koperasi menyelenggarakan pendidikan dan pelatihan bagi anggota, pengawas, pengurus dan karyawannya serta memberikan informasi kepada masyarakat tentang jatidiri, kegiatan dan kemanfaatan koperasi

f) Koperasi melayani anggotanya secara prima dan memperkuat gerakan koperasi dengan bekerjasama melalui jaringan kegiatan pada tingkat local, nasional, regional dan internasional, dan

g) Koperasi bekerja untuk pembangunanberkelanjutan bagi lingkungan dan masyarakatnya melalui kebijakan yang disepakati oleh anggota (Afandi, 2014).

Larangan Islam pada bunga (riba) mendorong adanya praktek syariah yang memberikan pelayanan jasa keuangan kepada sebagian masyarakat yang tidak bisa dilayani oleh jasa konvensional karena sistem bunga yang diterapkan. Sebagian masyarakat muslim berkeyakinan bahwa sistem konvensional tidak sejalan dengan sistem syariah Islam, oleh karena itu diharapkan dengan adanya sistem syariah dapat mengoptimalkan mobilitas dana masyarakat muslim (Lailatul khasanah, 2016) dalam (Rinovian \& Suarsa, 2018).

Perbandingan Koperasi Simpan Pinjam dan operasi Jasa Keuangan Syariah Baitul Maal wa Tamwil. Kedua lembaga ini memiliki persamaan dalam melakukan perjanjian pinjaman pada Koperasi Simpan Pinjam dan Perjanjian Pembiayaan pada Koperasi Jasa Keuangan Syariah Baitul Maal wa Tamwil. Perbedaannya terletak pada akad penyaluran dana, dimana Koperasi Simpan menggunakan akad utang piutang dalam kegiatan simpan pinjamnya. Sedangkan Koperasi Jasa Keuangan Syariah Baitul Maal wa Tamwil menggunakan akad kerjasama dalam kegiatan pembiayaannya, disamping itu juga terdapat akad jual beli dan sewa serta pinjam meminjam Qardh. Pada Koperasi Simpan Pinjam menggunakan akad Pinjaman yang pada akhirnya si peminjam harus memberikan imbalan berupa bunga pada Koperasi. Sedangkan pada Koperasi Jasa Keuangan Syariah Baitul Maal wa Tamwil menggunakan istilah pembiayaan yang mengharuskan di peminjam mengembalikan biaya pokok saja dan imbalan yang diberikan kepada KJKS BMT berupa bagi hasil dari pembiayaan tersebut. Koperasi Jasa Keuangan Syariah Baitul Maal wa Tamwil dapat menjadi penyalur dana Zakat, Infaq dan Shadaqah (ZIS) yang berperan sebagai fungsi sosial sesuai dengan Keputusan Menteri Koperasi dan Usaha Kecil dan Menengah Nomor 91/Kep/M.KUKM/IX/2004 Tentang Petunjuk Pelaksanaan Kegiataan Usaha Koperasi Jasa Keuangan Syariah (Ma'wa, 2013).

\section{Penyaluran Pembiyaan}

Banyak penelitian tentang dampak ekonomi dan sosial dari pembiyaan mikro dan hasilnya beragam. Afrane (2002), misalnya, mempelajari dampak dua intervensi keuangan mikro di Afrika (Sinapi Alba Trust (SAT) di Ghana selama tahun 1997 dan Program Pengembangan Keuangan Mikro Semeto (SOMED) di Afrika Selatan selama tahun 1998). Hasilnya menunjukkan bahwa intervensi keuangan mikro memberikan peningkatan pendapatan bisnis yang signifikan terhadap kehidupan dan pemberdayaan, khususnya perempuan. Konsumen keuangan mikro juga mengalami peningkatan kesejahteraan dalam masyarakat, dan memberikan kontribusi yang lebih besar untuk proyek sosial. Di sisi lain, mereka juga mengalami tekanan waktu yang lebih besar karena meningkatnya aktivitas bisnis yang memperburuk hubungan keluarga dan kehadiran aktifitas di gereja (Saad \& Duasa, 2011)

Kasmir (2012) menyatakan bahwa dalam bahasa latin, kredit berarti credere artinya percaya. Maksud dari percaya bagi pemberi kredit adalah ia percaya kepada penerima kredit bahwa kredit yang disalurkannya pasti akan dikembalikan sesuai perjanjian. Adapun pembiayaan adalah penyediaan uang atau tagihan yang dapat dipersamakan dengan itu, berdasarkan persetujuan atau kesepakatan antara bank dan pihak lain yang mewajibkan pihak yang dibiayai untuk mengembalikan uang atau tagihan tersebut setelah jangka waktu tertentu dengan imbalan atau bagi hasil. 
Pembiayaan yaitu pendanaan yang diberikan oleh suatu pihak kepada pihak lain untuk mendukung investasi yang telah direncanakan, baik dilakukan sendiri maupun lembaga (Muhammad, 2005) dalam (Prastiawati et al., 2016).

\section{Kriteria Penilaian Pemberian Pembiayaan}

Kriteria penilaian yang diberikan oleh bank untuk mendapatkan nasabah yang benar-benar menguntungkan dilakukan dengan analisis 5C-. Adapun analisis 5C menurut Kasmir (2012) adalah:

a. Character, Suatu keyakinan bahwa, sifat atau watak dari orang-orang yang akan diberikan kredit benar-benar dapat dipercaya, hal ini bisa dilihat dari latar belakang pekerjaan maupun yang bersifat pribadi seperti: gaya hidup dan keadaan keluarga.

b. Capacity. Untuk melihat kemampuan nasabah dalam bidang bisnis yang dihubungkan dengan pendidikan, kemampuan dalam memahami tentang ketentuan-ketentuan pemerintah, dan kemampuan dalam menjalankan usahanya. Sehingga akan terlihat kemampuannya dalam mengembalikan kredit yang disalurkan.

c. Capital. Untuk melihat penggunaan modal secara efektif, hal ini dapat dilihat dalam laporan keuangan dengan melakukan analisi rasio keuangan seperti: likuiditas, solvabilitas, rentabilitas dan ukuran lainnya.

d. Colleteral. Merupakan jaminan yang diberikan oleh calon nasabah baik berupa fisik maupun non fisik. Jaminan hendaknya melebihi jumlah kredit yang diberikan dan legalitasnya.

e. Condition. Melihat kondisi ekonomi dan politik sekarang dan di masa yang akan datang sesuai sektor masing-masing, serta prospek usaha dari sektor yang sedang dijalankan.

\section{Kualitas Pembiayaan}

Menurut peraturan Menteri Koperasi Negara Koperasi dan Usaha Kecil dan Menengah nomor 35.3/Per/M.KUKM/X/2007 tentang Pedoman Penilaian Kesehatan Koperasi Jasa Keuangan Syariah dan Unit Jasa Keuangan Syariah. Kesehatan Koperasi adalah kondisi atau keadaan koperasi dimana Koperasi dinyatakan sehat, cukup sehat, kurang sehat dan tidak sehat.

Tiga aspek penting dalam pembiayaan yakni Aman, Lancar, Menguntungkan. Berikut pemaparannya :

a) Aman, yakni keyakinan bahwa dana yang telah dilempar dapat ditarik kembali sesuai dengan kesepakatan.

b) Lancar, yaitu dana yang dilemparkan oleh BMT Mitra Hasanah bisa berputar dengan lancar dan cepat. Karena semakin cepat dan lancar perputaran dananya, maka pengembangan BMT Mitra Hasanah Semarang semakin baik.

c) Menguntungkan, yaitu perhitungan dan proyeksi yang tepat untuk memastikan bahwa dana yang dilempar akan menghasilkan pendapatan (Arifah, 2017)

Sebagai tambahan penilaian kualitas pembiyaan, selain menurut peraturan Menteri koperasi dan Usaha Kecil dan Menengah maka Bank Indonesia dalam Peraturan BANK INDONESIA Nomor 14/ 15 /PBI/2012 Tentang Penilian Kualitas Aset Bank Umum menggolongkan kualitas kredit menurut ketentuan sebagai berikut :

a. Lancar, suatu kredit dapat dikatakan lancar apabila :

1) Pembayaran angsuran pokok dan atau bunga tepat waktu

2) Memiliki mutasi rekening yang aktif

3) Bagian dari kredit yang dijamin dengan agunan tunai.

b. Dalam Perhatian Khusus, dikatakan dalam perhatian khusus apabila memenuhi kriteria yaitu :

1) Terdapat tunggakan pembayaran angsuran pokok dan atau bunga yang belum melampaui 90 hari

2) Kadang-kadang terjadi cerukan

3) Jarang terjadi pelanggaran terhadap kontrak yang diperjanjikan

4) Mutasi rekening reklatif aktif

5) Didukung dengan pinjaman baru.

c. Kurang Lancar, dikatakan kurang lancar apabila memenuhi kriteria sebagai berikut:

1) Terdapat tunggakan pembayaran angsuran pokok dan atau bunga yang telah melampaui 90 hari

2) Sering terjadi cerukan 
3) Terjadi pelanggaran terhadap kontrak yang diperjanjikan lebih dari 90 hari

4) Frekuensi mutasi rekening reklatif rendah

5) Terdapat indikasi masalah keuangan yang dihadapi debitur

6) Dokumen pinjaman lemah

d. Diragukan, dikatakan diragukan apabila memenuhi kriteria diantaranya :

1) Terdapat tunggakan pembayaran angsuran pokok dan atau bunga yang telah melampaui 180 hari

2) Terjadi cerukan yang bersifat permanen

3) Terjadi wanprestasi lebih dari 180 hari

4) Terjadi kapitalisasi bunga

5) Dokumen hukum yang lemah, baik untuk perjanjian kredit maupun pengikatan jaminan

e. Macet, dikatakan macet apabila memenuhi kriteria antara lain :

1) Terdapat tunggakan pembayaran angsuran pokok dan atau bunga yang telah melampaui 270 hari

2) Kerugian operasional ditutup dengan pinjaman baru

3) Dari segi hukum dan kondisi pasar, jaminan tidak dapat dicairkan pada nilai yang waja (Indonesia, 2012)

\section{Penyebab Pembiayaan Bermasalah}

Unsur- unsur yang menyebabkan pembiayaan bermasalah sebagai berikut :

1. Dalam pelaksanaan analisisnya, analisis kurang teliti sehingga apa yang seharusnya terjadi, tidak diprediksi sebelumnya. Dapat pula terjadi akibat kolusi dari pihak analisis pembiayaan dengan pihak debitur sehingga dalam analisisnya dilakukan secara subjektif (Wibowo \& Syaichu, 2013).

2. Dari pihak nasabah, Kemacetan pembiyaan dapat terjadi karena dua hal yaitu :

a. Adanya unsur kesengajaan. Dalam hal ini nasabah sengaja untuk tidak bermaksud membayar kewajibannya kepada bank sehingga pembiyaan yang diberikan macet. Atau dapat dikatakan tidak adanya unsur kemauan untuk membayar.

b. Adanya Unsur tidak sengaja. Artinya si debitur mau membayar, tetapi tidak mampu. Sebagai contoh terjadinya musibah seperti kebakaran, kena hama, kebanjiran,dan sebagainya. Sehingga kemampuan untuk membayar kredit tidak ada (Lailiyah, 2014).

\section{Kerangka Pemikirian}

Berdasarkan uraian diatas, maka dapat dirumuskan kerangka penelitian dapat diilustrasikan dalam Gambar. 2 berikut:

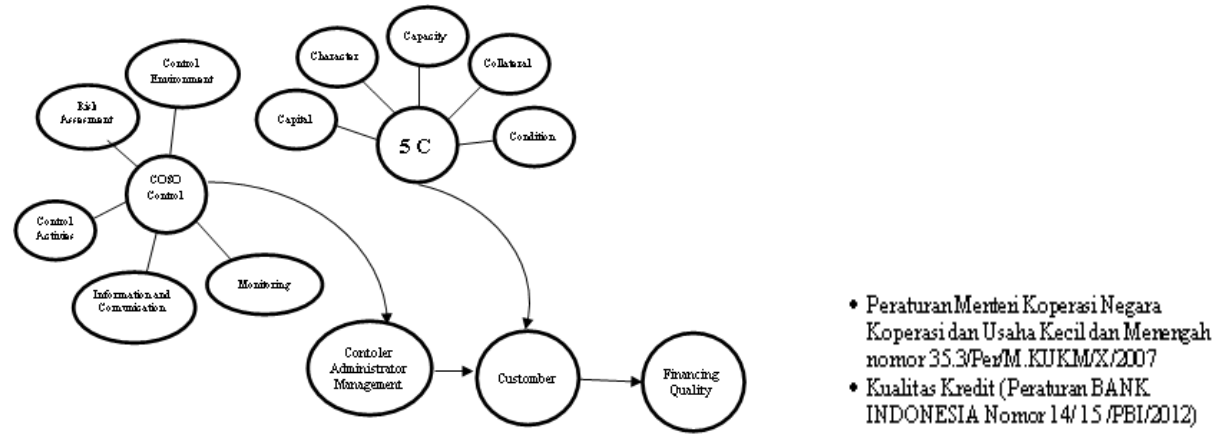

Gambar 2. Kerangka Pemikiran

\section{Focus Studi}

Dari urian pendahuluan dan kajian pustaka diatas maka efektifitas pengendalian internal dari kerangka pengendalian COSO akan meningkatkan kualitas pembiayaan dalam meminimalkan pembiayaan bermasalah di koperasi Syariah Baitul Muttaqin dan begitu pula sebaliknya.

Tujuan penelitian ini untuk mengetahui Kerangka Pengendalian COSO dalam mengendalikan prosedur pemberian pembiayaan, implementasi penerapan pada Koperasi Syariah Baitul Muttaqin sehingga akan meningkatkan kualitas pembiyaan. 
RQ: Bagaimana kerangka COSO mengendalikan prosedur pembiayaan sehingga meningkatkan kualitas pembiayaan pada Koperasi Syariaah Baitul Muttaqin?

\section{METODE}

\section{Sumber dan Data Penelitian}

Jenis data yang digunakan dalam penelitian ini adalah data sekunder. Data sekunder adalah data yang diolah dan diperoleh oleh peneliti dari pihak perusahaan maupun dari luar perusahaan yang berkaitan dengan permasalahan yang diteliti. Dalam penelitian ini, data diperoleh melalui studi kepustakaan dengan mempelajari sejumlah literatur, jurnal, paper, dan buku yang dinilai mampu memberikan kerangka teori bagi penelitian ini. Peneliti juga mempelajari informasi yang mendukung bagi penelitian ini yang tersedia di internet dan peraturan perundang-undangan mengenai pengelolaan keuangan negara dan kelembagaan institusi pemerintah. Hal ini dilakukan untuk memahami konteks permasalahan sehingga dapat melakukan analisis secara tajam dan mendalam. Data sekunder diperoleh dari Direktorat Jenderal Anggaran Departemen Keuangan berupa data Realisasi APBD dari tahun 2010 sampai dengan tahun 2016, data PDRB dari Badan Pusat Statistik, dan data investasi swasta dari BKPM.

\section{Variabel dan Definisi Operasional}

Klasifikasi variabel didasarkan atas kajian teoritis dan empiris sebagai acuan kerangka berfikir yang terdiri dari dua variabel.

Variabel eksogen adalah variabel yang mempengaruhi operasi dalam suatu model ekonomi dan variabel tersebut tidak dipengaruhi oleh setiap hubungan yang digambarkan oleh model tersebut. Variabel Eksogen dalam penelitian ini adalah Belanja Modal (X1) yang merupakan pengeluaran anggaran yang digunakan dalam rangka memperoleh atau menambah asset tetap dan asset lainnya yang memberi manfaat lebih dari satu periode akuntansi serta melebihi batasan minimal kapitalisasi aset tetap atau aset lainnya yang ditetapkan pemerintah dan Pendapatan Asli Daerah (X2) adalah pendapatan yang diperoleh daerah yang dipungut berdasarkan peraturan daerah sesuai dengan peraturan perundang-undangan. Arsyad (2004:17) berpendapat bahwa pertumbuhan ekonomi adalah perubahan Produk Domestik Regional Bruto (PDRB) per tahun yang dinyatakan dalam satuan persen.

Variabel endogen adalah variabel yang dipengaruhi oleh variabel eksogen. Variabel endogen dalam penelitian ini adalah Variabel endogen intervening yang merupakan variabel yang ikut berpengaruh ketika variabel eksogen mempengaruhi variabel endogen tergantung. Variabel endogen intervening dalam penelitian ini adalah Pertumbuhan Ekonomi (Y1) yang merupakan ilmu yang menggambarkan perkembangan suatu perekonomian dalam suatu tahun tertentu dibandingkan dengan tahun sebelumnya (Badrudin, 2012). Variabel endogen tergantung adalah variabel yang dipengaruhi oleh variabel eksogen maupun variabel endogen intervening. Variabel endogen tergantung dalam penelitian ini adalah Investasi Swasta (Y2) yang memiliki definisi Investasi sektor swasta adalah besarnya realisasi investasi/penanaman modal oleh masyarakat, baik berupa PMA maupun PMDN.

\section{HASIL DAN PEMBAHASAN Statistika Deskriptif}

Tabel 1. Hasil Uji Deskriptif

\begin{tabular}{cllll}
\hline & \multicolumn{1}{c}{ PAD } & \multicolumn{1}{c}{$\begin{array}{c}\text { BELANJA } \\
\text { MODAL }\end{array}$} & \multicolumn{1}{c}{ INVESTASI } & \multicolumn{1}{c}{ PDRB } \\
\hline Rata-Rata & \multicolumn{1}{c}{$3,260,458,191,239$} & $1,112,801,299,701$ & $7,839,196,278,785$ & $261,654,414,840,923$ \\
Maksimum & $39,322,613,624,142$ & $16,182,961,498,414$ & $95,851,268,047,020$ & $2,177,119,000,000,000$ \\
Minimum & $98,714,750,351$ & $108,997,026,000$ & $163,821,000$ & $5,389,831,565,710$ \\
\hline
\end{tabular}
Sumber: Data diolah (2018)

Dari data tersebut terlihat bahwa rata-rata PAD di seluruh provinsi di Indonesia adalah sebesar Rp3,260,458,191,239, rata-rata Belanja Modal adalah sebesar Rp1,112,801,299,701, rata- 
rata Investasi adalah sebesar $\mathrm{Rp} 7,839,196,278,785$ dan rata-rata PDRB adalah sebesar Rp261,654,414,840,923.

Selain itu, hasil dari uji deksriptif terlihat bahwa nilai tertinggi untuk PAD dimiliki oleh provinsi DKI Jakarta tahun 2016 yaitu sebesar Rp39,322,613,624,142, untuk variabel Belanja Modal dimiliki oleh provinsi DKI Jakarta tahun 2016 yaitu sebesar Rp16,182,961,498,414, untuk variabel Investasi dimiliki oleh provinsi Jawa Barat tahun 2013 sebesar Rp95,851,268,047,020 dan variabel PDRB yang dimiliki oleh DKI Jakarta tahun 2013 sebesar Rp2,177,119,000,000,000.

Dari tabel tersebut terlihat pula nilai terendah yang dimiliki masing-masing variabel, untuk nilai terendah variabel PAD dimiliki oleh provinsi Maluku Utara tahun 2010 dengan nilai sebesar Rp98,714,750,351, untuk variabel Belanja Modal dimiliki oleh provinsi Gorontalo tahun 2010 sebesar Rp108,997,026,000, untuk variabel investasi dimiliki oleh provinsi Maluku tahun 2014 sebesar Rp163,821,000, sedangkan untuk variabel PDRB dimiliki oleh provinsi Maluku Utara tahun 2010 sebesar Rp5,389,831,565,710.

\section{Analisis Induktif Dengan Partial Least Square (PLS)}

Pada penelitian ini peneliti menggunakan alat statisik WarpPLS 6.0 untuk melakukan uji hipotesis. Analisis induktif dengan menggunakan Partial Least Square (PLS) meliputi penelitian goodness of fit model (inner model) yang berfungsi untuk mengetahui kecocokan suatu model yang digunakan dalam penelitian dengan menggunakan variabel PAD, belanja modal, investasi dan pertumbuhan ekonomi. Hasil pengujian goodness of fit model dapat dilihat pada Tabel 2 berikut ini:

Tabel 2. Nilai goodness of fit model

\begin{tabular}{ll}
\hline APC $=0,353, \mathrm{P}<0,001$ & Good if $\mathrm{P}<0,05$ \\
ARS $=0,749, \mathrm{P}<0,001$ & Good if $\mathrm{P}<0,05$ \\
AVIF $=4,333$ & Good if $\leq 5$ \\
\hline
\end{tabular}

Sumber: Data diolah (2018)

Berdasarkan hasil pengujian model, nilai Average $R$-Squared (ARS) diperoleh hasil sebesar 0,749 dengan nilai $\mathrm{P}<0,001$. Berdasarkan hasil tersebut dapat disimpulan bahwa nilai ARS signifikan karena nilai $\mathrm{P}>0,05$, sedangkan nilai 0,749 menunjukkan bahwa variabel pada penelitian hanya mampu mempengaruhi variabel dependen sebesar $74,9 \%$ dan sisanya sebesar $25,1 \%$ dipengaruhi oleh faktor lain diluar variabel dalam penelitian. Nilai Average Path Coefficient (APC) sebesar 0,353 dengan nilai $\mathrm{P}<0,001$, hal ini berarti nilai APC signifikan karena nilai $\mathrm{P}<0,05$. Karena nilai APC yang dihasilkan signifikan, maka dapat dibuktikan bahwa variabel endogen dan eksogen memiliki hubungan sebab dan akibat baik secara langsung maupun tidak langsung. Pada model penelitian ini tidak terjadi multikolinearitas, hal tersebut terbukti dari nilai Average Variance Inflation Factor (AVIF) sebesar 4,333 yang nilainya $\leq 5$.

\section{Pengujian Hipotesis}

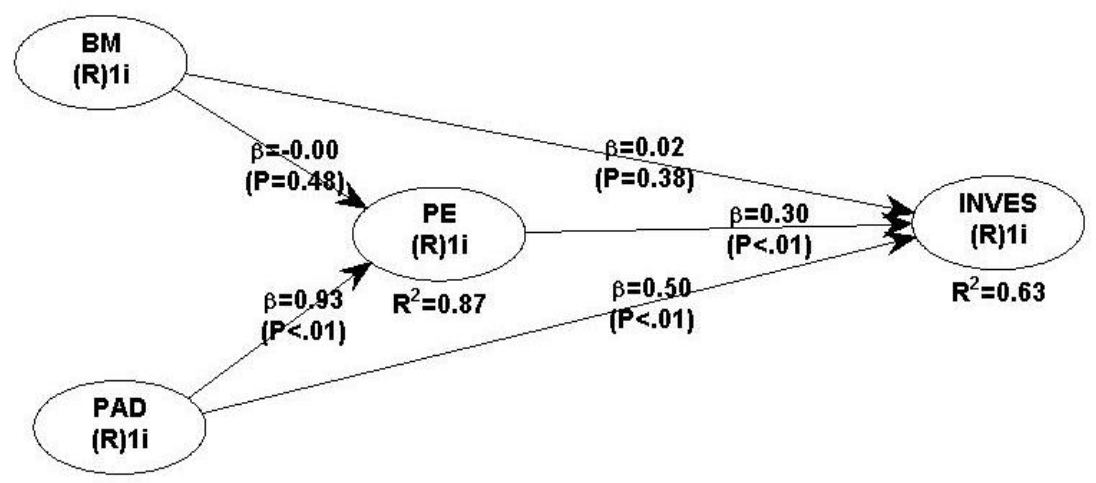

Gambar 2. Hasil Pengujian Hipotesis 
Dari hasil pengujian hipotesis yang terlihat pada gambar 2 maka diperoleh hasil bahwa hubungan yang terjadi antara belanja modal dan investasi swasta adalah hubungan yang positif dan signifikan, hubungan yang terjadi antara PAD dan investasi swasta juga menunjukkan hubungan yang positif dan signifikan. Pengujian lain juga dilakukan untuk menguji hubungan yang terjadi antara belanja modal dan pertumbuhan ekonomi namun hasilnya adalah negatif dan tidak signifikan. Selain itu hubungan yang terjadi antara PAD dan pertumbuhan ekonomi adalah positif dan signifikan, dan hubungan yang muncul antara pertumbuhan ekonomi dan investasi swasta adalah positif dan signifikan.

\section{Belanja Modal memiliki hubungan yang positif terhadap Investasi Swasta}

Hal tersebut ditunjukkan dengan nilai koefisien sebesar 0,02. Tetapi karena $p$-value sebesar 0,38 yang lebih besar dari tingkat signifikansi sebesar 0,05 maka pengaruh yang muncul tidak signifikan. Pengaruh tidak signifikan ini muncul karena kurangnya sampel yang mewakili populasi yang ada. Berdasarkan pengujian hipotesis yang dilakukan oleh peneliti maka hipotesis yang menyatakan bahwa belanja modal berpengaruh terhadap investasi swasta dapat diterima.

Hasil penelitian ini sesuai dengan penelitian yang dilakukan oleh Wang (2005), pada penelitian Wang (2005) dibahas mengenai complementary hypothesis yang menjelaskan bahwa belanja pemerintah pada infrasruktur yang diukur dengan belanja modal kemungkinan akan meningkatkan produktivitas marjinal dari modal swasta dan kemudian akan mendorong investasi swasta yang lebih yang kemungkinan akan mengarah pada crowd-in effect atau meningkatnya investasi swasta sebagai akibat dari pengeluaran pemerintah dalam hal belanja modal.

\section{PAD memiliki hubungan yang positif terhadap Investasi Swasta}

Dari pengujian tersebut terlihat bahwa hubungan yang terjadi antara PAD terhadap investasi swasta adalah positif dan signifikan, hal tersebut terlihat dari nilai koefisien yang dihasilkan, yaitu sebesar 0,50 dengan $p$-value $<0,01$. Berdasarkan pengujian hipotesis yang dilakukan oleh peneliti maka hipotesis yang menyatakan bahwa Pendapatan Asli Daerah berpengaruh terhadap investasi swasta dapat diterima.

Hasil penelitian ini sesuai dengan pengembangan pengujian hipotesis mengenai apabila tingkat PAD suatu daerah meningkat maka dapat dikatakan bahwa tingkat kesejahteraan masyarakat di daerah tersebut meningkat. Semakin tinggi tingkat pendapatan suatu masyarakat maka sumber pendapatan asli daerah yang berasal dari pajak juga akan semakin tinggi. Tingginya pendapatan masyarakat dapat menjadi cerminan bahwa tingkat kesejahteraan masyarakat di daerah tersebut baik sehingga wilayah tersebut dapat dijadikan wilayah yang berprospek bagus untuk dijadikan lahan investasi oleh pihak swasta dalam negeri atau asing. Sehingga dapat dikatakan di Indonesia, meningkatnya PAD akan memberi dampak meningkatnya investasi swasta.

\section{Belanja Modal berpengaruh negatif dan tidak signifikan terhadap pertumbuhan ekonomi}

Hal tersebut terlihat dari nilai koefisien jalur yang menunjukkan angka yang negatif yaitu sebesar $-0,003$ namun nilai $p$-value $=0,48$ yang diperoleh adalah sebesar yang lebih besar dari tingkat signifikansi yang telah ditentukan, dan angka p-value tersebut menunjukkan bahwa pengaruh yang diberikan adalah tidak signifikan. Berdasarkan pengujian hipotesis yang dilakukan maka dapat dikatakan bahwa hipotesis 3 yang menyatakan bahwa Belanja Modal berpengaruh terhadap Pertumbuhan Ekonomi tidak dapat diterima.

Pengaruh negatif dan tidak signifikan mungkin saja terjadi. Hal tersebut dikarenakan di Indonesia fenomena pertumbuhan ekonomi yang terjadi adalah pertumbuhan ekonomi eksklusif. Pertumbuhan ekonomi eksklusif dapat terjadi karena pembangunan yang dilakukan tidak berkualitas atau belum merata. Hasil yang diperoleh dalam penelitian ini sesuai dengan penelitian yang telah dilakukan oleh Sutawijaya (2013) yang menunjukkan bahwa pengeluaran pemerintah yang diukur menggunakan belanja modal memiliki pengaruh positif pada investasi swasta.

\section{Pendapatan Asli Daerah memiliki hubungan yang positif terhadap Pertumbuhan Ekonomi}

Hubungan tersebut terlihat dari nilai koefisien sebesar 0,93 dan tingkat $p$-value $<0,01$ yang nilainya lebih kecil dari tingkat signifikansi 0,05 yang nilainya lebih kecil dari tingkat signifikansi 
0,05. Berdasarkan hasil pengujian tersebut makan hipotesis 4 yang menyatakan bahwa Pendapatan Asli Daerah berpengaruh terhadap pertumbuhan ekonomi diterima.

Hasil penelitian yang diperoleh menunjukkan hal yang sesuai dengan penelitian yang dilakukan oleh Rori et, al (2016) dan Saraswati dan Ramantha (2018), pada penelitian terdahulu terlihat bahwa PAD memberikan pengaruh yang positif terhadap pertumbuhan ekonomi karena pada dasarnya peningkatan PAD merupakan akses meningkatnya pertumbuhan ekonomi. Sehingga apabila terjadi peningkatan PAD akan diikuti dengan peningkatan pertumbuhan ekonomi.

\section{Pertumbuhan Ekonomi memiliki hubungan yang positif terhadap Investasi Swasta}

Hasil pengujian hipotesis menunjukkan bahwa hubungan antara pertumbuhan ekonomi terhadap investasi swasta adalah positif dan signifikan. Hal tersebut terlihat dari nilai koefisien sebesar 0,3 dan p-value sebesar 0,01 yang lebih kecil dari tingkat signifikansi 0,05. Berdasarkan hasil olah data yang telah dilakukan oleh peneliti, maka dapat disimpulkan bahwa hipotesis yang menyatakan bahwa Pertumbuhan Ekonomi berpengaruh terhadap Investasi Swasta dapat diterima.

Hasil penelitian ini sesuai dengan penelitian yang dilakukan oleh Sutawijaya (2013) yang menunjukkan bahwa PDRB akan memberikan efek positif pada investasi swasta. Jika suatu daerah memiliki tingkat pertumbuhan ekonomi yang tinggi maka hal tersebut memiliki arti bahwa penyediaan infrasruktur di daerah tersebut adalah baik. Sehingga wilayah tersebut dapat dikatakan layak untuk menjadi lahan investasi.

\section{KESIMPULAN \\ Kesimpulan}

Secara umum tujuan penelitian ini adalah untuk membuktikan hubungan yang terjadi antara belanja modal, PAD, pertumbuhan ekonomi dan investasi swasta. Berdasarkan hasil pembentukan hipotesis dan pengujian yang telah dilakukan oleh peneliti, maka dapat disimpulkan beberapa hasil dari penelitian ini.

Hasil dari penelitian ini terlihat hubungan yang terjadi antara belanja modal dan investasi swasta adalah hubungan yang positif dan signifikan, sehingga dapat dikatakan bahwa hipotesis 1 diterima. Hasil pengujian untuk hipotesis 2 menunjukkan hal yang serupa, dalam penelitian ini hipotesis 2 diterima karena hubungan yang terjadi antara PAD dan investasi swasta adalah positif dan signifikan. Pengujian lain juga dilakukan untuk hipotesis 3, hasil pengujian untuk hipotesis 3 menunjukkan hal yang sebaliknya, dalam penelitian ini hipotesis 3 tidak diterima karena hubungan yang terjadi antara belanja modal dan pertumbuhan adalah negatif dan tidak signifikan. Selain itu, pengujian yang dilakukan untuk menguji hipotesis 4 menunjukkan bukti bahwa hubungan yang terjadi antara PAD dan pertumbuhan ekonomi adalah positif dan signifikan, oleh karena itu hipotesis 4 dapat diterima. Hasil pengujian yang terakhir dilakukan untuk menguji hipotesis 5 , hasil dari pengujian hipotesis tersebut terlihat bahwa hubungan yang muncul antara Pertumbuhan Ekonomi dan Investasi Swasta adalah positif dan signifikan, maka hipotesis 5 dalam penelitian ini dapat diterima.

\section{Saran}

Saran bagi penelitian selanjutnya adalah peneliti dapat menambah variabel lain yang dapat mendukung pengembangan penelitian ini, sehingga hubungan dengan variabel lain dapat lebih terlihat. Selain itu bagi penelitian yang akan datang disarankan menggunakan data realisasi anggaran yang terbaru karena pada penelitian ini ketersediaan data merupakan kelemahan kami sehingga kami tidak bisa menggunakan data realisasi anggaran yang terkini yaitu tahun 2017 karena data tersebut belum tersedia.

\section{DAFTAR PUSTAKA}

Abdullah, Syukriy, Abdul Halim, 2006. "Studi Atas Belanja Modal pada Anggaran Pemerintah Daerah dalam Hubungannya dengan Belanja Pemeliharaan dan Sumber Pendapatan", Jurnal Akuntansi Pemerintah Volume 2 Nomor 2.

Arsyad, Lincolin. 2010. Ekonomi Pembangunan. Edisi 5, Yogyakarta: UPP STIM YKPN. 
Ayu, Diah, Kusumadewi dan Rahman, Arief, 2007, "Flypaper Effect Pada Dana Alokasi Umum (DAU) Dan Pendapatan Asli Daerah (PAD) Terhadap Belanja Daerah Pada Kabupaten/Kota Di Indonesia", JAAI, Vol. 11, No. 1, Juni.

Badrudin, Rudy. (2012). Ekonomika Otonomi Daerah. Yogyakarta: UPP STIM YKPN. Yogyakarta.

Djojohadikusumo, Sumitro. 1994. Perkembangan Pemikiran Ekonomi: Dasar Teori Ekonomi Pertumbuhan dan Ekonomi Pembangunan. Jakarta: LP3ES.

Erden Lutfi and Holcombe Randall G. 2005. The Effects of Public Investment On Private Investment In Developing Countries. Public Finance Review. 33: 575-602.

Erlina, Rasdianto, 2013, Akuntansi Keuangan Daerah Berbasis Akrual, Penerbit Brama Ardian

Ernita, Dewi, Syamsul Amar, dan Efrizal Syofyan. 2013. Analisis Pertumbuhan Ekonomi, Investasi, dan Konsumsi Di Indonesia. Jurnal Kajian Ekonomi. 1: 176-193.

Hakim, Abdul. 2013. Indeks Pembangunan Manusia di Indonesia. Jurnal Economica.

Halim, A. 2007. Akuntansi Sektor Publik Akuntansi keuangan daerah. Edisi Revisi. Salemba Empat. Jakarta

Harianto. 2007. Akuntansi Sektor Publik. Badan Penerbit Universitas Diponegoro. Semarang

Hjerppe, Reino, Pellervo Hamalainen, Jaakko Kiander, and Matti Viren. 2007. Do government expenditures increase private sector productivity? Cross-country evidence. International Journal of Social Economics. 34:345-360.

Peraturan Presiden Nomor 42 Tahun 2005 tentang Komite Percepatan Penyediaan Infrastruktur.

Rori, Chindy Febri, Antonius Y. Luntungan, Audie O Niode. 2016. Analysis Of The Influence of Local Own Revenue to Economic Growth In the Province of North Sulawesi In 2010-2013. Jurnal Berkala Ilmiah Efisiensi. 16 (02).

Saragih, Juli Panglima. 2003. Desentralisasi Fiskal dan Keuangan Daerah dalam Otonomi. Cetakan Pertama. Penerbit Ghalia Indonesia: Jakarta.

Saraswati, Ida Ayu, I Wayan Ramantha. 2018. Pengaruh Pendapatan Asli Daerah Terhadap Pertrumbuhan Ekonomi Dengan Belanja Modal dan Investasi Swasta Sebagai Pemoderasi. E-Jurnal Akuntansi Universitas Udayana. 24(1)

Sutawijaya, Adrian and Zulfahmi. 2013. Faktor-Faktor yang Mempengaruhi Investasi Swasta di Indonesia. Trikonomika. 12: 32-39.

Tambunan, Tulus. 2006. Upaya-upaya Meningkatkan Daya Saing Daerah. Diakses dari http://www.kadin-indonesia.or.id.

Todaro, Michael P. and Stephen C. Smith. 2006. Economic Development. 9th Edition. New York: Pearson Addison Wesley.

Undang-Undang No. 33 Tahun 2004 Tentang Perimbangan Keuangan Antara Pemerintah Pusat dan Pemerintah Daerah.

Undang-Undang Nomor 25 Tahun 2007 tentang Penanaman Modal.

Undang-Undang Nomor 32 Tahun 2004 tentang Pemerintahan Daerah. 
Wahyuningsih, Tri. 2012. Dampak Investasi Pemerintah dan Investasi Swasta Terhadap Pertumbuhan Ekonomi dan Kesejahteraan Masyarakat di Provinsi Maluku. Jurnal IQTISHODUNA. 8: 1-24.

Wang, Baotai. 2005. Effects of Government Expenditure on Private Investment: Canadian Empirical Evidence. Canada. Empirical Economics. 30: 493-504

[http://bkpm.go.id]. Diakses 24 Mei 2017

[http://bps.go.id]. Diakses 31 Mei 2017 